\title{
Virtual Reality and retailers: possibilities and limitations from a systematic review
}

Elias Florivaldo Otrenti, Ingrid Winkler

Senai Cimatec, Brazil,

Abstract: Many areas apply Virtual Reality (VR) technology and visualized realistic digital models open opportunities to marketing and sales area. This study aims to review recent research of VR usage for sales and evaluate the effect of these technologies on customer's pleasures during purchase decision maker. Based on a systematic literature review (SLR) allows proving the efficiency of VR models with intuitive interfaces affect user's behaviors towards on hedonism and purchase decision maker.

Keywords: virtual reality, hedonic, purchase decision, augmented reality.

\section{TITLE ARIAL 14, BOLD AND UPPERCASE, JUSTIFIED, SIMPLE SPACE (in Portuguese), WITH A MAXIMUM OF THREE LINES}

Resumo: A Realidade Virtual é uma tecnologia com aplicações em diversas áreas e visualizar os produtos através de modelos digitais realistas oferece diversas oportunidades para o setor de vendas. O Objetivo desse trabalho é caracterizar o conhecimento atual sobre o uso da RV aplicado em vendas e avaliar o impacto das tecnologias no prazer do cliente durante a jornada de compra. A estratégia utilizada foi uma Revisão Sistemática da Literatura que permitiu comprovar a eficiência que os modelos de realidade virtual associados a interfaces intuitivas influenciam as atitudes dos usuários nos sentidos relacionados ao hedonismo e a tomada de decisão de compra.

Palavras-chave: realidade virtual, hedonismo, decisão de compra, realidade aumentada. 


\section{INTRODUCTION (ARIAL 12, must start on the second page)}

\section{THE ENTIRE MANUSCRIPT SHOULD BE WRITTEN IN ENGLISH.}

In 2017 a study pointed out that in 2020 the technologies Virtual Reality (VR), Augmented Reality (AR) and Mixed Realities (MR) will have a sales growth in the order of 21 times greater than in 2016 [1]. VR and RA are already recognized by retailers as important tools when applied to sales and the technologies are expected to generate an economic impact of $\$ 29.5$ billion in the United States in 2020 [2].

Their interactions on VR environments with users are relevant factors for the purchase decision process when they are evaluating a product in a virtual way. A pleasant shopping journey provided through interactive VR environments with customers influences the final product purchase decision [3].

Hedonomy is a concept that relates ergonomics to the pleasure of using products: "if the emphasis of Ergonomics is on preventing embarrassment and user safety when interacting with everyday systems, hedonomy focuses on promoting pleasure with these same systems". In this sense, hedonomia studies the user's affective relationships with the product. It can be through multisensory experiences that motivate purchasing decisions, allowing emotional buying desires to dominate [4]

To affect consumer hedonomy, VR models present information about products in a clear, objective and updated way through an interactive customer interface [5]. The greatest success in sales and the pleasure purchase journey of users, while using VR models as a tool to purchase decision-making process influence towards closing the deal [6].

Head Mounted Display (HMD) is a device with stereoscopic vision able to provide consumer an understanding of the sizes and locations of objects and the direct interaction with a 3D computational model that represents the product, improves the company's perception of reliability to customers who buy online [7-13-14].

The study aims to review recent research about the use of VR in sales and to evaluate the impact of technologies on the customer's pleasure during the purchase decision process.

This paper is organized as follows: Section 2 describe the methodology. Section 3 describes the results observed and discuss them. Finally, Section 4 presents our conclusions and further research needed.

\section{METHODOLOGY (ARIAL 12)}

The first stage of a systematic review is the elaboration of the question that will guide the searches, in a structured way, which leads to more efficiency of the review by enhancing the identification of relevant evidence and consequentially more accurate answers. [7]

To this end we used the acronym SPICE (figure 1), which is based on PICO (population, intervention, comparison and results); the population component was divided into two parts, defining and perspective; results has been replaced by assessment to conduct a broader evaluation that incorporates results and affects [7]. 
Figure 1. Spice

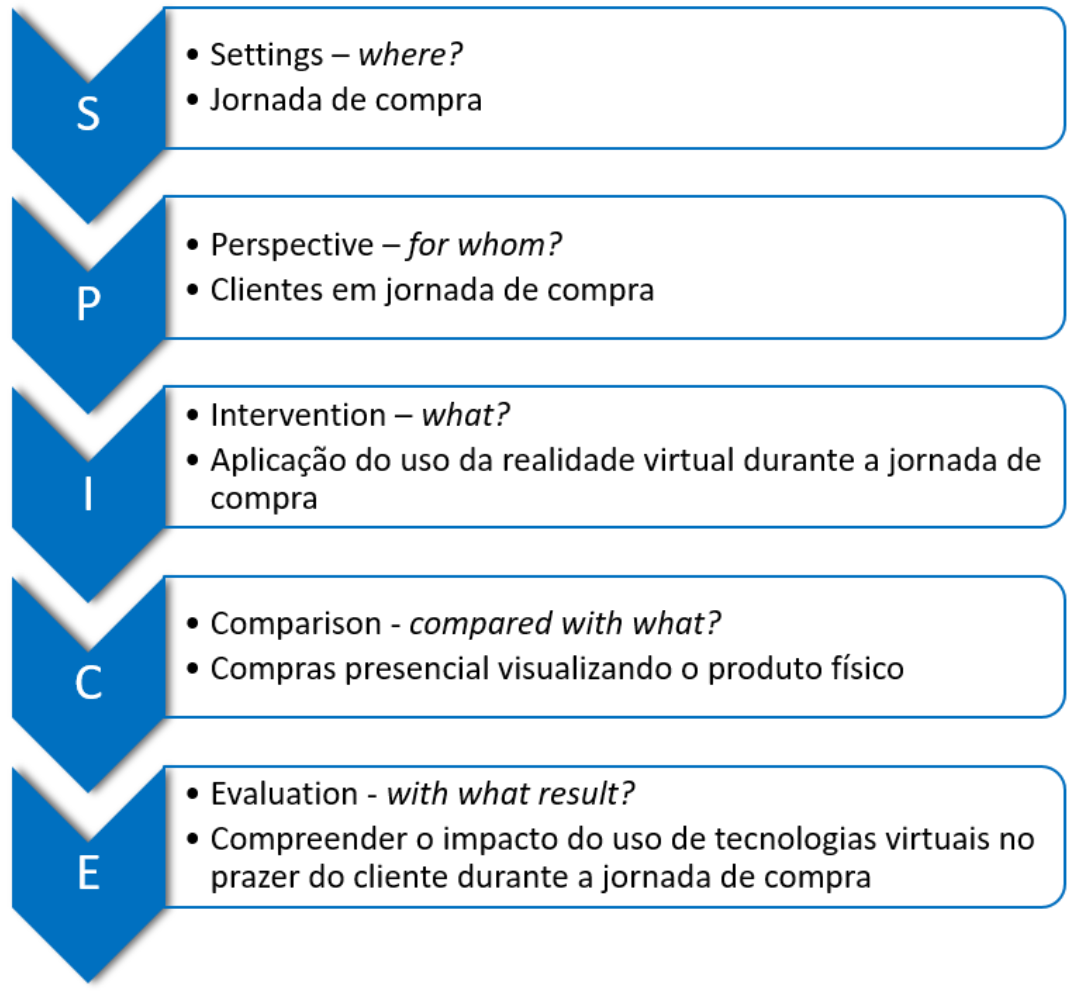

Figura 1 - Método SPICE adaptado de (Booth, 2006) pelo autor

Therefore, the guiding question was "Is VR able to stimulate a pleasure during purchase journey for users?" Then, keywords and search strategies were selected in the Science Direct.

To select the articles, the title and abstract were read. In case of doubts about the content, the article was read in its entirety for inclusion or not. Texts that were not scientific articles and those that didn't have a product sales model using virtual reality were excluded. The flowchart for searching and selecting articles is shown in figure 2 . The information extracted from the articles is also presented in the SPICE format, considering that this acronym allows the elaboration of the question and, consequently, the search for answers in the articles.

After reading the articles, two papers were excluded because they were not related to the question, therefore twelve papers make up the results below. 
Figure 2. Fluxograma

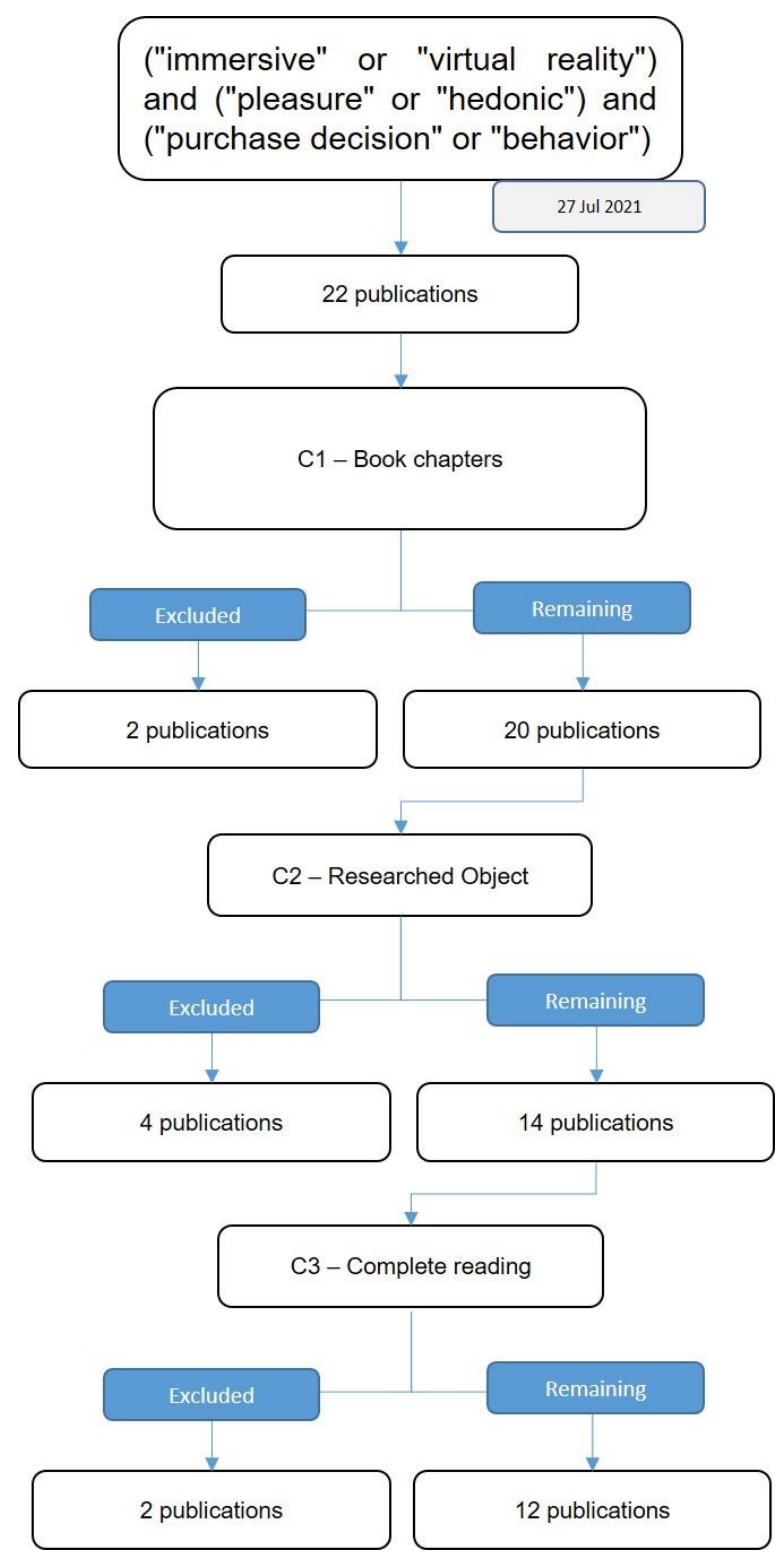

Figura 2 - Fluxograma de identificação e seleção dos artigos, fonte o autor.

\section{RESULTS AND DISCUSSION (ARIAL 12)}

The publications selected to compose the knowledge base for this work are listed in Table 1. The results and discussions are presented in three sections: hardware, VR model and purchase journey. 
Table 1. Spice Reading table

\begin{tabular}{|c|c|c|c|c|c|}
\hline Ref. & $\begin{array}{c}\mathbf{S} \\
\text { (Where?) }\end{array}$ & $\begin{array}{c}\mathrm{P} \\
\text { (for Whom?) }\end{array}$ & $\begin{array}{c}\text { I } \\
\text { (What?) }\end{array}$ & $\begin{array}{c}\text { C } \\
\text { (comparison with What?) }\end{array}$ & $\begin{array}{c}\text { E } \\
\text { (with What Results?) }\end{array}$ \\
\hline [3] & $\begin{array}{l}\text { Furniture online } \\
\text { shopping }\end{array}$ & $\begin{array}{l}300 \text { customers answers } \\
\text { questions about VR } \\
\text { experience. }\end{array}$ & $\begin{array}{l}\text { Apply Oculus Rift with } \\
\text { monitor in online shopping }\end{array}$ & $\begin{array}{l}\text { Comparisson between 3D web } \\
\text { based model and HMD } \\
\text { visualization. }\end{array}$ & $\begin{array}{l}\text { Playfulness interfaces can influency } \\
\text { hedonimocs atributes and } \\
\text { informativeness interfaces affects } \\
\text { towards purchase decision-maker } \\
\text { process. }\end{array}$ \\
\hline [5] & Online retailers & $\begin{array}{l}\text { Female consumers with } 19 \\
\text { to } 25 \text { years old. }\end{array}$ & AR applications & $\begin{array}{l}\text { Comparioson the impacts of } \\
\text { using AR on the purchase } \\
\text { journey. }\end{array}$ & $\begin{array}{l}\text { AR technologies should be focused } \\
\text { on functionality and ease of use as } \\
\text { the main factors for success among } \\
\text { users. }\end{array}$ \\
\hline [6] & $\begin{array}{l}\text { Ray-Ban online } \\
\text { virtual try }\end{array}$ & $\begin{array}{l}\text { Customer RA usage during } \\
\text { online purchase jorney. }\end{array}$ & $\begin{array}{l}\text { AR model development to } \\
\text { online retailers }\end{array}$ & $\begin{array}{l}\text { Model to evaluate the } \\
\text { customers perceived atributes } \\
\text { when usign virtua try. }\end{array}$ & $\begin{array}{l}\text { RA usage and positives impacts } \\
\text { towards positive satisfactions during } \\
\text { purchase jorney. }\end{array}$ \\
\hline [8] & Virtual Turism & $\begin{array}{l}1756 \text { customers answers } \\
\text { questions about VR } \\
\text { experience. }\end{array}$ & $\begin{array}{l}\text { Questionaries outputs from } \\
\text { selected public }\end{array}$ & $\begin{array}{l}\text { Comparison the pleasures } \\
\text { levels whem visit online and real } \\
\text { places. }\end{array}$ & $\begin{array}{l}\text { HMD can provide escapism and } \\
\text { provide a pleasure virtual turism. }\end{array}$ \\
\hline [9] & $\begin{array}{l}\text { Different stages in } \\
\text { the purchase } \\
\text { journey }\end{array}$ & $\begin{array}{l}\text { Customers in online stores } \\
\text { and physical stores. }\end{array}$ & $\begin{array}{l}\text { Investigate how the sales } \\
\text { platform environment } \\
\text { influences the purchase } \\
\text { decision }\end{array}$ & $\begin{array}{l}\text { Comparisson three basic } \\
\text { elements from a store (online or } \\
\text { physical) }\end{array}$ & $\begin{array}{l}\text { Model that evaluates the influence of } \\
\text { store design (visual aids), } \\
\text { environment and social on the user's } \\
\text { purchase decision }\end{array}$ \\
\hline [10] & $\begin{array}{l}\text { Online customer } \\
\text { purchase jorney }\end{array}$ & E-commerce retailers & $\begin{array}{l}\text { Perform experiment to } \\
\text { understand the impact of } \\
\text { the background colors of } \\
\text { VR models }\end{array}$ & $\begin{array}{l}\text { There are few studies on the } \\
\text { impact of the background colors } \\
\text { of VR models during the } \\
\text { purchase journey. }\end{array}$ & $\begin{array}{l}\text { The background color influences the } \\
\text { user's purchase decision and Blue } \\
\text { was the color with positive sales } \\
\text { effects. }\end{array}$ \\
\hline [11] & $\begin{array}{l}\text { Not specified by } \\
\text { author }\end{array}$ & $\begin{array}{l}\text { The author specifies only } \\
\text { the sample quantity, } 110 \\
\text { points. }\end{array}$ & $\begin{array}{l}\text { Study on the use of } \\
\text { simulators to stimulate } \\
\text { purchase decision making } \\
\text { process. }\end{array}$ & $\begin{array}{l}\text { Comparison between two } \\
\text { racing simulators }\end{array}$ & $\begin{array}{l}\text { The use of car simulators through } \\
\text { video-game platforms positively } \\
\text { influences the user's purchase } \\
\text { intention. }\end{array}$ \\
\hline [12] & $\begin{array}{l}\text { Online purchase } \\
\text { jorney }\end{array}$ & VR customers. & $\begin{array}{l}\text { Propõe um modelo que } \\
\text { pare de dois tipos de } \\
\text { involvimento alto e baixo }\end{array}$ & $\begin{array}{l}\text { Proposes a model with two } \\
\text { levels of involvement high and } \\
\text { low. }\end{array}$ & $\begin{array}{l}\text { The high and low engagement } \\
\text { models stimulate consumer reactions } \\
\text { such as satisfaction and brand loyalty. }\end{array}$ \\
\hline [13] & Shopping-Centers & $\begin{array}{l}\text { Reseach splits in two } \\
\text { groups: Experienced VR } \\
\text { users and inexperienced } \\
\text { VR users. }\end{array}$ & $\begin{array}{l}\text { Oculus Rift DK2 and a } \\
\text { Santa-Clauss ride VR } \\
\text { model. }\end{array}$ & $\begin{array}{l}\text { VR usage to reduce perception } \\
\text { of crowding in customers. } \\
\text { Measure witb semantic scale (- } \\
3 ;+3) \text {. }\end{array}$ & $\begin{array}{l}\text { Escapism from reality can provide a } \\
\text { pleasure purchase jorney in shopping- } \\
\text { centers }\end{array}$ \\
\hline [14] & Germany & $\begin{array}{l}611 \text { Germany consumers } \\
\text { with variable } \\
\text { characteristics of age, } \\
\text { gender and living area }\end{array}$ & $\begin{array}{l}\text { Propose a framewrork to } \\
\text { enhance VR model for } \\
\text { sales. }\end{array}$ & $\begin{array}{l}\text { Compar all results reggardless } \\
\text { of VR involvement or } \\
\text { knowledge. }\end{array}$ & $\begin{array}{l}\text { HMD usage have be increasing and } \\
\text { can be apply to functional and } \\
\text { entrainment }\end{array}$ \\
\hline [15] & AR apps & Germany consumers & $\begin{array}{l}\text { AR applications and their } \\
\text { acceptance by the market }\end{array}$ & $\begin{array}{l}\text { Questionnaire to obtain a } \\
\text { comparison between RA with } \\
\text { marker-based and without } \\
\text { marker. }\end{array}$ & $\begin{array}{l}\text { The use of AR is well accepted by } \\
\text { users and provides a user pleasure } \\
\text { purchase journey. }\end{array}$ \\
\hline [16] & Germany & Most students, 145 total. & $\begin{array}{l}\text { AR to enhance purchase } \\
\text { decision-maker process }\end{array}$ & $\begin{array}{l}\text { Comparisson of AR hedonic } \\
\text { affects on users }\end{array}$ & $\begin{array}{l}\text { The nostalgia stimulated by AR Lego } \\
\text { application, positive psychological } \\
\text { impacts and cause positive impacts } \\
\text { on the user's purchase decision. }\end{array}$ \\
\hline
\end{tabular}

Table 1 - Identification and summary of articles, by author.

\subsection{Hardware}

HMDs are stereoscopic devices capable of immersing the user in virtual environments to understanding the size and proportions of the products they are viewing. The escapism associated with the pleasure and a playfulness interface provides during the users shopping journey contributes to exploring hedonic aspects of the consumer. [1]

The use of HMDs as a device to reduce and calm feelings can stimulated by perceived crowds in shopping centers contributes to the increase in the pleasure of users during purchases and has a positive impact on purchasing decisions. [3-4] 
The HMD capability immersion provides high levels of pleasure to users. A pleasure purchase journey for users and the intuitive disposition of product information are key factors for hedonic motivation systems. [2]

AR as tool for a virtual product try adds positive values for sales, brand recognition and user pleasure during the purchase journey using cell phones and tablets. Fun and intuitive interfaces drive towards the purchase decision-making process. [6]

\subsection{RV Model}

Proposed model that considers the social aspects, store design (visual resources) and physical and online store environment are relevant factors in the users's shopping journey [8] and the blue backgrounds environments for models viewed by users in online stores contribute positively to providing a cognitive experience for users [7].

AR applications are efficient in enhance users's hedonic attributes and providing a pleasure purchase journey for users who use virtual fitting rooms to view and make the purchase decision [9-11-12].

Forza Motorsport 2 and 3 games associated with the Logitech steering wheel and pedals simulator and viewed on a 32 "LCD TV, provided users with hedonic stimuli and positively influenced the car purchase decision after driving for virtually 10 minutes. [10].

\subsection{Purchase journey}

The user's needs at each stage of the purchase journey is important to measure the amount of information and interactions available in the VR model. A pleasant purchase journey and focus user's attention to the relevant attributes of the product evaluated for making a purchase decision are the relevant ones to leverage sales. [5]

VR can affect psychological stimuli regarding to hedonism and escapism that provide users with sense of pleasure when visiting virtual tourist spots or choosing to purchase tangible products on online retailers. The technologies with the greatest immersion power are HMDs, which constantly improve the quality of the resolution, precision and ergonomics of the devices. [2-3-4]

The VR technology limits for implementation in physical stores and online retailers are the values of HMD devices, the development of 3D models and interfaces with users. The technological barrier can be a limiting factor depending on the age group of users. [8] 


\section{CONCLUSION (ARIAL 12)}

VR technologies are already present in people routine and with several applications and limitations. Many technologies were enhanced applications by benefit to users through VR and AR and the success of this technology has often reached global levels of popularity, for example: Instagram filters that use AR to add virtual elements to the content shared by users.

Immersive stereoscopic visualization devices have become popular over the years and their technological developments opportunities are the main attractions for users and developers of this technology. Motion sickness and powerful hardware to run immersive technology were the main limitations found in researches. The values for implementing VR are more accessible and a greater choice of devices contributes to its increasing popularity.

The VR models platforms to development offers many options to explore the virtual resources available to contribute to the user's purchase journey. To simulate or try the products virtually while shopping online was a positive factor for user's purchase decision-making and highlight the needs to develop efficient VR models. The researches has limitations regarding on data collection and based on the major results are interviews or questionnaires answered buy users. Future researches has the opportunity to improve data collections buy using non-invasive sensors on human body to measure body reactions.

The user's purchase journey pleasure can be enhanced by several aspects and regarding to the user's hedonomy when using VR technologies to make the product purchase decision. The interface between the product and the user is very important to achieve the benefits that the visualization or virtual simulation of the product.

There was no comparison between the same 3D virtual models applied in different VR technologies or the usage of multiple VR classes according to population's characteristics.

VR is an important tool that can stimulate psychological aspects related to hedonomy. VR technologies have a good maturity and market acceptance, they can provide pleasure during their use and the development of more intuitive interfaces favor the decision making of users.

\section{REFERENCES (ARIAL 12)}

1SUPERDATA-RESEARCH. The MMO \& MOBA games market report, 2016. 2016.

2STATISTA, Available. The statistics portal. Web site: https://www.statista.com/statistics/969418/worldwide-forecast-virtual-reality-market-bysegment/, 2018.

${ }^{3}$ KANG, Hyo Jeong; SHIN, Jung-hye; PONTO, Kevin. How 3D Virtual Reality Stores Can Shape Consumer Purchase Decisions: The Roles of Informativeness and Playfulness. Joumal of Inte ractive Marketing, v. 49, p. 70-85, 2020.

${ }^{4}$ HANCOCK, Peter A.; PEPE, Aaron A.; MURPHY, Lauren L. Hedonomics: The power of positive and pleasurable ergonomics. Ergonomics in design, v. 13, n. 1, p. 8-14, 2005.

${ }^{5} \mathrm{SCHOLZ}$, Joachim; DUFFY, Katherine. We ARe at home: How augmented reality reshapes mobile marketing and consumer-brand relationships. Joumal of Retailing and Consumer Services, v. 44, p. 11-23, 2018. 
${ }^{6}$ PANTANO, Eleonora; RESE, Alexandra; BAIER, Daniel. Enhancina the online decision-making process by using augmented reality: A two country comparison of youth markets. Journal of Retailing and Consumer Services, v. 38, p. 81-95, 2017.

${ }^{7} \mathrm{BOOTH}, \mathrm{A}$. (2006). Clear and present questions: formulating questionsfor evidence basd practice. Library Hi Tech. 24:3, 355-368.

${ }^{8} \mathrm{KIM}$, Myung Ja; HALL, C. Michael. A hedonic motivation model in virtual reality tourism: Comparing visitors and non-visitors. International Journal of Information Management, v. 46, p. 236249, 2019.

${ }^{9}$ ROGGEVEEN, Anne L.; GREWAL, Dhruv; SCHWEIGER, Elisa B. The DAST framework for retail atmospherics: The impact of in-and out-of-store retail journey touchpoints on the customer experience. Journal of Retailing, v. 96, n. 1, p. 128-137, 2020.

${ }^{10} \mathrm{ETTIS}$, Saïd Aboubaker. Examining the relationships between online store atmospheric color, flow experience and consumer behavior. Journal of Retailing and Consumer Services, v. 37, p. 4355, 2017.

${ }^{11}$ PAPAGIANNIDIS, Sawas; SEE-TO, Eric; BOURLAKIS, Michael. Virtual test-driving: The impact of simulated products on purchase intention. Joumal of Retailing and Consumer Services, v. 21, n. 5, p. 877-887, 2014.

${ }^{12} \mathrm{COWAN}$, Kirsten; KETRON, Seth. A dual model of product involvement for effective virtual reality: The roles of imagination, co-creation, telepresence, and interactivity. Journal of Business Research, v. 100, p. 483-492, 2019.

13 VAN KERREBROECK, Helena; BRENGMAN, Malaika; WILLEMS, Kim. Escaping the crowd: An experimental study on the impact of a Virtual Reality experience in a shopping mall. Computers in Human Behavior, v. 77, p. 437-450, 2017.

${ }^{14} \mathrm{HERZ}$, Marc; RAUSCHNABEL, Philipp A. Understandina the diffusion of virtual reality glasses: The role of media, fashion and technology. Technological Forecasting and Social Change, v. 138, p. 228-242, 2019

${ }^{15}$ RESE, Alexandra et al. How augmented reality apps are accepted by consumers: A comparative analysis using scales and opinions. Technological Forecasting and Social Change, v. 124, p. 306319, 2017.

${ }^{16} \mathrm{HINSCH}$, Chris; FELIX, Reto; RAUSCHNABEL, Philipp A. Nostalqia beats the wow-effect: Inspiration, awe and meaningful associations in augmented reality marketing. Journal of Retailing and Consumer Services, v. 53, p. 101987, 2020. 